\title{
Review \\ Natural Killer Cells in Post-Transplant Lymphoproliferative Disorders
}

\author{
Cecilia Nakid-Cordero ${ }^{1,+} \oplus^{-}$, Marine Baron ${ }^{1,2,+} \mathbb{C}$, Amélie Guihot ${ }^{1,3, \ddagger}$ and Vincent Vieillard ${ }^{1, *, \ddagger}$ \\ 1 Centre d'Immunologie et des Maladies Infectieuses (CIMI-Paris), INSERM U1135, CNRS ERL8285, Sorbonne \\ Université, Hôpital Pitié-Salpêtrière, 75013 Paris, France; cecilia.nakid-cordero@inserm.fr (C.N.-C.); \\ marine.baron@aphp.fr (M.B.); amelie.guihot@aphp.fr (A.G.) \\ 2 Service d'Hématologie, Groupe Hospitalier Pitié-Salpêtrière Assistance Publique-Hôpitaux de \\ Paris (AP-HP), 75013 Paris, France \\ 3 Groupe Hospitalier Pitié-Salpêtrière, Département d'Immunologie, Assistance Publique-Hôpitaux de \\ Paris (AP-HP), 75013 Paris, France \\ * Correspondence: vincent.vieillard@sorbonne-universite.fr; Tel.: +33-1-42-17-75-24 \\ + These first authors contributed equally. \\ $\ddagger$ These last authors contributed equally.
}

Citation: Nakid-Cordero, C.; Baron, M.; Guihot, A.; Vieillard, V. Natural Killer Cells in Post-Transplant Lymphoproliferative Disorders. Cancers 2021, 13, 1836. https:// doi.org/10.3390/cancers13081836

Academic Editors: Paola Vacca and Laura Chiossone

Received: 23 February 2021

Accepted: 7 April 2021

Published: 12 April 2021

Publisher's Note: MDPI stays neutral with regard to jurisdictional claims in published maps and institutional affiliations.

Copyright: (c) 2021 by the authors. Licensee MDPI, Basel, Switzerland. This article is an open access article distributed under the terms and conditions of the Creative Commons Attribution (CC BY) license (https:// creativecommons.org/licenses/by/ $4.0 /)$.
Simple Summary: Post-transplant lymphoproliferative disorders (PTLDs) are life-threatening complications. The clinical and pathological spectrum of PTLD is broad; however, most cases of PTLD are associated with Epstein-Barr virus (EBV) infection and the use of immunosuppression treatment required to prevent graft rejection. While T-cell impairment is known to play a critical role in the immunopathogenesis of EBV complications post-transplantation, the role of natural killer (NK) cells remains more elusive. NK cells are key elements of the innate immune system that use a sophisticated array of activating, costimulatory, and inhibitory receptors to kill virally infected and/or cancerous cells. In this review we highlight the role of NK cells in the pathogenesis of PTLD, and also identify future avenues for NK cell therapy research.

Abstract: Post-transplant lymphoproliferative disorders (PTLDs) are life-threatening complications arising after solid organ or hematopoietic stem cell transplantations. Although the majority of these lymphoproliferations are of B cell origin, and are frequently associated with primary Epstein-Barr virus (EBV) infection or reactivation in the post-transplant period, rare cases of $\mathrm{T}$ cell and natural killer (NK) cell-originated PTLDs have also been described. A general assumption is that PTLDs result from the impairment of anti-viral and anti-tumoral immunosurveillance due to the long-term use of immunosuppressants in transplant recipients. T cell impairment is known to play a critical role in the immune-pathogenesis of post-transplant EBV-linked complications, while the role of NK cells has been less investigated, and is probably different between EBV-positive and EBV-negative PTLDs. As a part of the innate immune response, NK cells are critical for protecting hosts during the early response to virus-induced tumors. The complexity of their function is modulated by a myriad of activating and inhibitory receptors expressed on cell surfaces. This review outlines our current understanding of NK cells in the pathogenesis of PTLD, and discusses their potential implications for current PTLD therapies and novel NK cell-based therapies for the containment of these disorders.

Keywords: natural killer cells; post-transplant lymphoproliferative disorders; Epstein-Barr virus

\section{Introduction}

Natural killer (NK) cells were identified more than four decades ago as innate lymphocytes with the ability to lyse tumor cells without the need for prior sensitization [1,2]. NK cells are mounted with a panoply of activating and inhibitory receptors on their surface, suggesting that different NK cell subsets can be identified based on the assortment of NK receptors that are expressed. The integration and balance of the activating and 
inhibitory signals from the ligand/receptor interactions dictates the status of NK cell activation. For instance, healthy cells express no or a minimal level of ligands for NK cell activating receptors, such as NKG2D and the natural cytotoxicity receptors (NCR: NKp30, NKp44 and NKp46), but express high levels of the major histocompatibility complex class I (MHC-I) molecules, which ligate to inhibitory receptors, such as NKG2A, Ig-like transcript 2 (ILT-2) and the killer immunoglobulin-like (KIR) family, to protect them from NK attack. Conversely, pathogenic target cells can downregulate MHC-I expression and/or overexpress ligands for NK cell activating receptors to trigger NK cell functions [3]. Thus, upon activation, NK cells release cytotoxic granules containing perforin and granzymes to directly lyse tumor cells, in a similar fashion to activated cytotoxic $\mathrm{T}$ cells, or indirectly by antibody-dependent cellular cytotoxicity (ADCC), triggered through binding of the Fc $\gamma$ RIIIA receptor (CD16) on NK cells by the Fc fragment of IgG antibodies. In addition, NK cells produce large amounts of chemokines and cytokines such as interferon gamma $(\mathrm{IFN}-\gamma)$ and tumor necrosis factor alpha (TNF- $\alpha)$, which also play major roles in tuning and controlling adaptive immune responses [4].

Due to their intrinsic capacities, NK cells play important roles in protection against viruses and tumor growth $[5,6]$. Studies in both animals and humans suggest that NK cells are critical in the host defense against Epstein-Barr virus (EBV), persistently carried by more than $85 \%$ of the adult human population. In vitro studies have clearly shown killing of EBVinfected B cells by autologous NK cells [7,8], whereas individuals with selective primary NK cell deficiency exhibit an increased susceptibility to EBV, associated with fatal primary infection or the development of EBV-associated cancers [9-11]. In addition, depletion of NK cells upon EBV infection of humanized mice favors EBV-associated tumorigenesis and exacerbates infectious mononucleosis (IM) [12,13], a self-limiting disorder characterized by extensive proliferation of polyclonal EBV-specific $\mathrm{CD} 8^{+} \mathrm{T}$ cells in response to primary EBV infection. Importantly, preferential proliferation and accumulation of early-differentiated $\mathrm{CD}_{5}{ }^{\mathrm{dim}} \mathrm{NKG}^{2} \mathrm{~A}^{+} \mathrm{KIR}^{-} \mathrm{NK}$ cells was observed in immunocompetent children with acute IM [8], or after in vitro co-culture of NKG2A ${ }^{+} \mathrm{NK}$ cells with autologous EBV-infected B cells $[14,15]$. Mechanistically, it was reported that peptides derived from EBV latent proteins can impair the recognition of the inhibitory NKG2A receptor, despite being presented by HLA-E, resulting in activation of differentiated, cytotoxic NK cells for the immune control of EBV [16,17].

Compared to IM, less is known about EBV-specific immune control by NK cells in EBV-driven lymphomas, such as in post-transplant lymphoproliferative disorders (PTLDs). PTLDs are heterogeneous tumors arising after solid organ transplantation (SOT) and hematopoietic stem cell transplantation (HSCT), often related to EBV [18,19]. EBV-positive PTLDs usually arise early after transplantation, in close relation with heavy immunosuppressive therapy, and are believed to result from altered NK and T cell responses against EBV-infected lymphocytes, while the pathogenesis of EBV-negative PTLD is less clear [18,20-22] (Table 1). Although most PTLDs are of B cell origin, the emergence of posttransplant NK lymphoproliferative diseases has also been observed in PTLD development. These malignancies are usually classified amongst T/NK cell PTLD in the World Health Organization (WHO) classification [23]. Previously, an analysis of 130 cases of T/NK cell PTLD reported that they occurred late, at a median of 66 months after transplantation, and that they were frequently extranodal [24]. Since, eight other central nervous system or nasal NK/T cell lymphoma patients have been reported, all but two being EBV-related [25,26]. $\mathrm{T} / \mathrm{NK}$ PTLDs usually do not respond to a decrease in immunosuppression and the median survival is six months. Notably, overall survival for patients with EBV+ T/NK PTLD was described to be significantly better than for patients with EBV disease. This reveals that true NK cell PTLDs are very rare entities with poor prognosis. Diagnosis relies on pathologic examination, immunohistochemistry, peripheral blood immunophenotyping and, when necessary, T-cell receptor (TCR) sequencing showing the germline configuration. 
Table 1. Characteristics of EBV-positive and EBV-negative PTLDs.

\begin{tabular}{cccc}
\hline WHO Classification & Post-Transplant Onset & Age at Transplant & EBV Association \\
\hline Nondestructive PTLD & Generally early & Adult and pediatric & Generally EBV-positive \\
\hline Polymorphic PTLD & Frequently early & Adult and pediatric & Generally EBV-positive \\
\hline Monomorphic PTLD & & & \\
\hline B-cell lymphomas & Both early and late & $\begin{array}{c}\text { More frequent in adult } \\
\text { than pediatric }\end{array}$ & $\begin{array}{c}\text { EBV-positive and } \\
\text { EBV-negative }\end{array}$ \\
\hline T-cell and NK-cell lymphomas & Generally late & Generally adult & Frequently EBV-negative \\
\hline Classic Hodgkin Lymphoma-like PTLD & Generally late & Generally adult & Frequently EBV-positive \\
\hline
\end{tabular}

\section{The Role of NK Cells in the Immunopathology of PTLDs}

NK cells are critical actors in innate immunity during early responses against both viral infections and tumor growth. In the context of PTLDs, NK cells probably play different roles according to EBV status of the tumor. Indeed, EBV-positive and EBV-negative PTLDs show different patterns in terms of time from transplantation to PTLD development, age at PTLD diagnosis, and tumor morphologies (Table 1).

\subsection{NK Cells and EBV-Positive PTLDs}

EBV-positive PTLDs frequently develop early after transplantation, when immunosuppression is at its highest level and immune surveillance is weak. During this critical period, EBV reactivation is frequently observed in transplant recipients, resulting from a loss in the balance between infected cells and cytotoxic lymphocytes. Additionally, transplant recipients who develop primary EBV infection are at high risk of PTLD development due to uncontrolled EBV-driven proliferation of infected lymphocytes.

NK cells are known to play a major role in the control of EBV infection in the early post-transplant period, as NK cell reconstitution in peripheral blood reaches normal values within the first month after SOT or HSCT, several months before T cell and B cell restoration [27-31]. In a recent study in adult SOT recipients, NK cell lymphopenia was observed in $70 \%$ of EBV-positive PTLD diagnoses [32]. In that same study, the proportion of peripheral blood CD56 ${ }^{\text {bright }} \mathrm{CD} 16^{-}$and $\mathrm{CD} 56^{\mathrm{dim}} \mathrm{CD} 16^{+} \mathrm{NK}$ cells was similar between PTLD patients and transplant controls, independently of SOT type. Previous work by Baychelier et al. described increased proportions of CD56 ${ }^{\text {bright }} \mathrm{CD} 16^{-}$cells in 11 adult lung or liver recipients who developed EBV-positive PTLD, when compared to healthy SOT recipients [33]. Meanwhile, a study by Wiesmayr et al. in pediatric heart or lung transplant recipients showed that EBV-positive PTLD patients displayed increased proportions of early-differentiated CD56 ${ }^{\mathrm{dim}} \mathrm{CD} 16^{-}$cells and CD56- CD16 ${ }^{+} \mathrm{NK}$ cells in peripheral blood [34]. Interestingly, early-differentiated CD56 ${ }^{\mathrm{dim}} \mathrm{NKG} 2 \mathrm{~A}^{+} \mathrm{KIR}^{-} \mathrm{CD} 16^{-} \mathrm{NK}$ cells also accumulate in immunocompetent children with acute IM and are known to preferentially recognize autologous B cells with lytic EBV infection [8].

The scarcity of data about NK cell phenotype and subtype distribution reported at PTLD diagnosis might be related to the variability between studies in terms of type of organs transplanted. Transplant-related alterations are associated with differences in pre-transplant conditioning regimes and maintenance immunosuppressive therapy. In allo-HSCT patients and SOT recipients who received anti-thymocyte globulin (ATG), NK cells are depleted during pre-transplant conditioning treatment, which is followed by posttransplant NK cell reconstitution, starting with CD56 bright cells [35-37]. An accumulation of CD56 $6^{\text {bright }} \mathrm{NK}$ cells in blood may also be seen in patients treated with azathioprinebased regimens, which selectively deplete CD56 ${ }^{\mathrm{dim}}$ NK cells (Lord and Shows, 2017), or with cyclosporine, which preferentially blocks CD56 ${ }^{\mathrm{dim}}$ cell proliferation and favors an accumulation of CD56 ${ }^{\text {bright }} \mathrm{NK}$ cells in blood [38]. On the other hand, it has been observed 
that $\mathrm{CD} 56^{\text {bright }}$ and CD56 $6^{\mathrm{dim}}$ subsets regain normal proportions within the first year in hepatic transplant recipients [39].

The age at transplantation and at PTLD diagnosis are other factors that probably influence NK cell phenotype. The early-differentiated CD $56^{\mathrm{dim}} \mathrm{NKG}^{2} \mathrm{~A}^{+} \mathrm{KIR}^{-} \mathrm{CD} 16^{-} \mathrm{NK}$ cell subset is progressively replaced by differentiated CD $56^{\mathrm{dim}} \mathrm{KIR}^{+}$during the first decade of life $[8,40]$, while the level of expression of NKG2D, NKp30 and NKp46 decreases with age [40]. The modulation of activating receptors NKp46 and NKG2D is also observed in the NK cells of adult and pediatric SOT recipients at EBV-positive PTLD diagnosis. NKG2D is an important activating receptor against EBV-positive PTLD tumors, as they express NKG2D ligands such as MIC-B [41]. However, EBV miRNAs from the BART (Bam HI-A region rightward transcript-2) family are also expressed in EBV-transformed B cells during PTLD and have been found to traffic with MIC-B mRNA, limiting the expression of MIC-B protein at the surface of tumor cells [42]. The specific ligands of NKp46 in EBV-positive PTLDs remain undescribed, but NKp46 downmodulation is also observed in different virus-induced cancers and has been related to low cytotoxic capacity [34,37,43,44].

A recent concept in NK-cell biology is that of functional exhaustion. In contrast with T cells, NK cell exhaustion probably results from the progressive loss of expression of several activating receptors, followed by the accumulation of inhibiting receptors, including the expression of inhibitory immune checkpoints, such as PD-1, Tim-3 and Lag-3, leading to cell dysfunction [45] (Figure 1). Another alteration of the NK cell phenotype at EBVpositive PTLD diagnosis, which often appears alongside one or several of the previously mentioned alterations, is the expression of the PD-1 receptor [32,34]. PD-1 expression by NK cells is rare in healthy individuals [46], but is often observed in association with gammaherpesvirus infection in kidney transplant recipients with chronic EBV reactivation [47], in pediatric thoracic recipients with high EBV loads [34], and in human-herpesvirus8 (HHV-8)-related Kaposi sarcoma patients [44]. PD-1 expression by NK cells is also frequently observed in the context of cancers in which the PD-1 ligands PD-L1/L2 are highly expressed by tumor cells $[48,49]$, which is frequently the case for EBV-positive PTLDs [50,51]. In pediatric EBV-positive PTLD patients with high PD-1 expression by NK cells, the low functional capacity of NK cells, in terms of both IFN- $\gamma$ production and CD107a cytotoxicity marker expression, can be recovered after in vitro PD-1/PD-L1 blockade [34]. A study of adult lung recipients observed diminished NK cell cytotoxicity against various lymphoma cell lines at PTLD diagnosis [33], while IFN- $\gamma$ production after IL-12 and IL-18 stimulation was superior in NK cells of adult SOT recipients at PTLD diagnosis, compared to transplant controls $[32,33]$. Treatment with anti-PD-1 antibodies resulted in increased cytotoxicity and IFN- $\gamma$ production of peripheral NK cells from multiple myeloma patients carrying high proportions of PD- $1^{+} \mathrm{NK}$ cells, suggesting that PD-1 could be a target for an immunotherapeutic strategy in EBV-positive PTLD patients [52]. However, immune-checkpoint blockade in transplant recipients is a delicate task due to the risk of transplant rejection, an issue that currently limits the utilization of anti-PD-1 and anti-PD-L1 antibodies in PTLD patients [53,54]. 


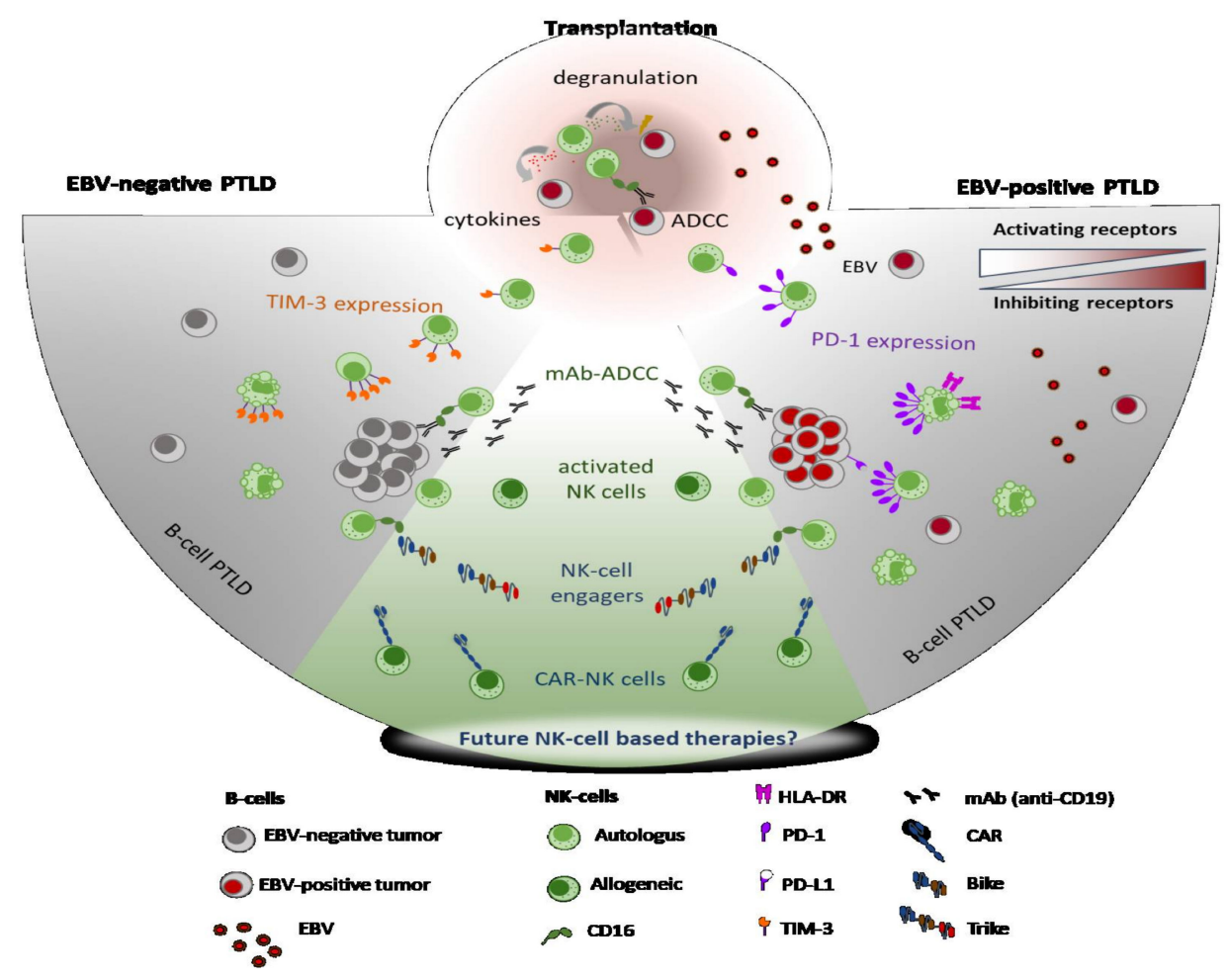

Figure 1. Natural killer (NK) cells are the first lymphocyte compartment to be quantitatively and functionally restored after solid organ or hematopoietic stem-cell transplantation and are the first line of protection against Epstein-Barr virus (EBV)-infected cells and tumor development. At the recognition of EBV-infected or tumor targets, NK cells release perforin and granzymes to mediate the lysis of target cells. Meanwhile, NK cells produce IFN- $\gamma$ to limit viral infection. Transplant recipients with increasing EBV loads are at high risk of EBV-positive PTLD development and are often treated with rituximab, a monoclonal antibody $(\mathrm{mAb})$ that binds to the CD20 molecule expressed at the surface of B cells. In such cases, NK cells also contribute to the defense of the host by inducing antibody-dependent cell cytotoxicity (ADCC) though the recognition of therapeutic mAbs by CD16. However, solid organ transplantation (SOT) recipients often present increased proportions of NK cells expressing the PD-1 inhibiting immune checkpoint receptor in relation with high EBV loads in blood. During EBV-positive post-transplant lymphoproliferative disorders (PTLDs), NK cells progressively increase PD-1 expression together with the NKG2A inhibiting receptor, while NKG2D and NKp46 activating receptors are downmodulated, a phenotype that might impact NK cell functional capacity against the tumor. In addition to this phenotype, constant NK cell activation has been observed and related to increased activation-induced cell death (AICD), resulting in peripheral NK cell lymphopenia at PTLD diagnosis. In the case of EBV-negative PTLDs, NK cells show increased expression of the Tim-3 inhibiting immune checkpoint receptor, and increased apoptosis has also been associated with mild NK cell lymphopenia at EBV-negative PTLD diagnosis. Besides their central role as cytotoxic innate lymphocytes, NK cells can also be exploited for therapeutic use. Their most frequent role is their cytotoxic activity through ADCC in the context of mAb treatments such as chimeric (rituximab) or humanized (obinutuzmab) anti-CD20 mAbs. Furthermore, autologous infusions of activated NK cells have been used in HSCT recipients with PTLD. Currently, several strategies for NK cell activity enhancement are under development and present characteristics that could allow their utilization in transplanted populations. Bi-specific and tri-specific NK cell engagers, for example, facilitate NK cell synapsing with tumor targets in a very specific manner, and offer the advantage that they can be administered to boost NK cell responses of the host or be coupled with either autologous or allogeneic infusions of NK cells. CAR-NK cells, on the other hand, promise an "off-the-shelf" cellular therapy, so far showing low toxicity and high specificity in immunocompetent recipients. 
Another important parameter to consider when studying NK cell phenotype in transplant recipients is the EBV pre-transplant serology. While most adult transplant recipients have encountered EBV before transplantation, pediatric transplant recipients are less likely to and therefore more frequently develop primary EBV primary infection after transplantation. A recent study by our team observed that the NK cells of adult PTLD patients overexpress the HLA-DR activation marker, with the highest levels observed in patients who acquired primary EBV infection post-transplant [32]. In that same study, NK cell activation was associated with high EBV loads and seemed to cause NK cell apoptosis, as those patients also presented with high proportions of IFN- $\gamma$-producing NK cells, PD-1 overexpression and profound NK cell lymphopenia [32] (Figure 1). Altogether, the different alterations of NK cells that have been described at EBV-positive PTLD diagnosis seem to be directly related to the interaction between EBV and NK cells in the context of immunosuppression and reduced presence of adaptive $\mathrm{T}$ lymphocytes.

Besides the direct role of NK cells in the control of both EBV infection and tumor development, NK cells also share complementary roles with other cellular components of immunity. Given the impaired state of the immune system under immunosuppressive therapy, such complementary roles become essential to maintain the delicate balance between immunity and virus/tumor development. The increased capacity of NK cells to produce IFN- $\gamma$ at EBV-positive PTLD diagnosis might partially compensate for the low levels of latent EBV-specific CD4 ${ }^{+}$Th1 cells frequently observed after transplantation $[47,55,56]$. Thus, concomitant reduction of Th1 and NK cells limits two subsets specialized in producing high levels of the anti-viral cytokines IFN- $\gamma$ and TNF- $\alpha$. Furthermore, the cytotoxic capacity of NK cells is probably essential for keeping EBV-infected cells under control, especially when considering that EBV-specific CD8 ${ }^{+} \mathrm{T}$ cells also show several defects in EBV-positive PTLD patients. Finally, the synergistic work between the B and NK cell compartments results in interaction between antibody production and CD56 ${ }^{\mathrm{dim}} \mathrm{CD} 16^{+} \mathrm{NK}$ cell-directed ADCC.

Although most studies describing NK cells in EBV-positive PTLDs are based on observations made in peripheral blood populations, the genetic characterization of the EBV-positive PTLD tumor microenvironment (TME) has started to demonstrate the role of NK cells. The comparison of gene expression profiles between EBV-positive and EBVnegative tumors showed positive regulation of genes associated with innate immunity and cytotoxicity in EBV-positive PTLDs [57]. However, the actual capacity of NK cells to infiltrate the tumor microenvironment (TME) has not been proven and NK cell anti-tumor cytotoxicity might be limited due to the tolerogenic environment created by EBV latent proteins and miRNAs $[17,58-60]$.

\subsection{NK Cells and EBV-Negative PTLDs}

The role of NK cells in EBV-negative PTLD has been less described than in its EBVpositive counterpart. EBV-negative PTLDs have historically represented a small minority of PTLDs, but their proportion has constantly increased in recent years [21], currently representing 30-50\% of PTLDs depending on different cohorts [20,21,61-63]. As EBV-negative PTLDs develop late after transplantation, 5-10 years or more [64], the identification of predictive biomarkers, and therefore prevention, is difficult. EBV-negative PTLDs generally present as aggressive monomorphic lymphomas (Table 1).

A recent immunological characterization of 39 EBV-negative PTLDs allowed us to observe different immune alterations between EBV-positive and EBV-negative PTLDs [32]. We observed a mild NK cell lymphopenia in EBV-negative PTLD patients, suggesting that NK cell lymphopenia could be a common aspect between PTLDs, although the presence of EBV clearly exacerbated NK cell depletion. More interestingly, NK cells from EBVnegative PTLD patients displayed higher Tim-3 expression than NK cells from EBV-positive samples [32] (Figure 1). The Tim-3 immune checkpoint is an inhibitory receptor normally expressed by mature NK cells [65], but its expression is generally increased in various types of cancer [66-70]. In patients with lung adenocarcinoma, treatment with anti-Tim3 antibodies resulted in increased cytotoxicity and IFN $-\gamma$ production of peripheral NK 
cells [70], suggesting that Tim-3 could be a target for an immunotherapeutic strategy in EBV-negative PTLD patients. However, the safety of the Tim-3 immune-checkpoint blockade in transplant recipients remains unknown, especially when considering the risk of graft rejection.

\section{Putative Strategies Exploiting NK Cell Therapy to Treat PTLDs}

Considering the major role of NK cells in the immunopathology of PTLD, we asked if effector functions of NK cells could be used as a therapeutic option in PTLD, whatever their origin. However, very few data are available for PTLD patients because of the rarity of the disease and the frequent exclusion of these patients from clinical trials. Thus, we focused on NK-based regimens in non-Hodgkin lymphoma (NHL) patients, assuming that they could be extended to PTLD, subject to confirmation of safety. Indeed, safety is a major concern in transplant recipients because of the risk of graft rejection in the case of non-targeted immunotherapy.

\subsection{NK Cell-Mediated ADCC}

In the context of lymphoma, NK cell-mediated ADCC can be exploited through the use of therapeutic monoclonal antibodies (mAbs) targeting an antigen, such as CD20. Several reports have demonstrated that ADCC is an important mechanism contributing to the efficacy of rituximab in follicular lymphoma [71-73]. It is known that the valine (V) to phenylalanine $(\mathrm{F})$ transition at amino-acid position 176 of FcyRIIIa induces a higher affinity to human IgG1 to lead a more effective mediation of ADCC [74]. Indeed, polymorphisms of FcyRIIIa (homozygous V/V allele) are independently associated with response to rituximab and progression-free survival (PFS) in follicular lymphoma patients [71,72]. In the same way, favorable genotypes of FcyRIIIa positively affect the outcomes of lymphoma patients treated with idiotype vaccination [75]. Conversely, FcyRIIIa polymorphisms do not correlate with outcomes for lymphoma patients treated with chemotherapy without rituximab, confirming that the positive effects of favorable genotypes are not due to the underlying clinical behavior of the disease, but to immunologic mechanisms. [76]. A new generation of glycoengineered anti-CD20 mAbs, such as obinutuzumab, leading to afucosylation and enhanced affinity for the FcyRIIIa, induced greater ADCC than rituximab and are currently used for NHL treatment [77] (Figure 1). Of note, FcyRIIIa expression is negatively regulated by the metalloproteinase ADAM17, which cleaves this receptor from the surface of NK cells after activation. Preventing this downregulation in tumor-infiltrating NK cells could be a potential target of treatment. A phase I/II trial testing rituximab combined with an ADAM17 inhibitor is currently being conducted in patients with large B cell lymphoma (NCT02141451).

\subsection{NK Cell Engagers}

In another attempt to enhance the natural function of tumor-infiltrating NK cells, antibody constructs known as bispecific killer engagers (BiKE) have been developed, which bring these cells into contact with tumor cells in an antigen-specific manner via CD16 [78-82]. In addition to bridging contact, the juxtaposition of NK cells and targets facilitates other activating receptor interactions and other missing-self signals. Nevertheless, BiKE failed to target NK cell expansion, as CD16 ligation does not trigger proliferation and survival [83]. To resolve this issue, tri-specific killer engager (TriKE) molecules were designed to induce specific NK cell-mediated killing, while providing a cytokine signal to drive NK cell expansion (Figure 1). Indeed, these molecules are composed of two singlechain variable fragments (scFvs), one engaging the CD16 on NK cells and one engaging a tumor-associated antigen, connected by small linkers and IL-15, a cytokine that stimulates the expansion of NK cells, and their ADCC functions. TriKE demonstrated a superior capacity for stimulating NK proliferation and persistence, and a higher killing capacity of these NK cells compared to that seen when treated using BiKE [84-86]. Considering lymphoid malignancies, AFM13 is the first BiKE that specifically recruits NK cells through CD16A 
binding while targeting $\mathrm{CD} 30$, and which was given to relapsed or refractory Hodgkin lymphoma (R/R HL) patients. In a phase 1 study, AFM13 showed a good safety profile, but only short-term NK cell activation, low response rates (23\% for patients receiving optimal doses) and short response duration (median five months) [87]. It was combined with pembrolizumab to facilitate innate and adaptive immune system recruitment in $R / R$ HL [88]. Outcomes were very positive, with an $83 \%$ overall response rate (ORR) and a median response duration of 10 months, however it is difficult to assess the individual contributions of AFM13 and pembrolizumab to the efficacy observed. Several trials testing AFM13 in lymphoma treatment are currently under way (NCT02321592, NCT03192202, NCT04074746). For B cell proliferations such as chronic lymphoid leukemias (CLL) and lymphomas, TriKE therapies have been tested in vitro and have demonstrated stimulation of NK cell expansion and enhancement of effector functions associated with tumor growth delay and survival improvement, compared to untreated or BiKE-treated mice $[86,89,90]$.

\subsection{NK Cell Enhancement with Cytokines}

Another way to enhance NK cell function in vivo is through the use of IL-2 or IL-15, which are known to be key regulators of NK cell activity. While an increase in NK cell activity against malignant cells was seen with this method, limited success was observed in patients treated with cytokines such as IL-2. In that respect, we have learned that IL-2 therapy results in activation of regulatory T cells (Tregs), which inhibits NK cell function and limits their anti-tumor activity [91,92]. Treatment with IL-15 was associated with lower toxicities than IL-2 treatment, and few objective responses [93-95]. To augment the antitumor immunity induced by such approaches, N-803 IL-15 "superagonist" is now being tested in combination with NK cell adoptive treatment, immune checkpoint inhibitors or tumor-targeting mAbs in several clinical trials. In patients with R/R NHL, N-803 combined with rituximab resulted in an ORR of $48 \%$ in a phase 1 study [96].

\subsection{Adoptive NK Cell Transfer}

The advantages of anti-tumor immunity mediated by NK cells can also be implemented using adoptive cellular therapy. Autologous NK cell infusions were the first major focus of adoptive NK cell therapy, but failed to produce significant therapeutic effects in hematological or solid malignancies, possibly due to the lack of KIR-ligand mismatch [97-99]. Moreover, the expansion efficiency and functional status of autologous NK cells were still limited because patients were often heavily pretreated, whereas allogeneic NK cells from healthy donors could have a stronger graft-versus-tumor effect. These considerations motivated the development of treatments based on allogeneic NK cells, which can usually be collected from haploidentical or unrelated donors, or from umbilical cord blood, clonal cell line NK-92 or stem cell-derived NK cells. The first studies were undertaken in the setting of HSCT or acute myeloid leukemia (AML), because of the major role of NK cells in post-transplantation immune reconstitution [100-102]. For B cell lymphoma patients, haploidentical NK cell infusions plus IL-2 and rituximab after lymphodepleting chemotherapy induced a $29 \%$ ORR $(n=4)$. Donor NK cells persisted for at least one week after infusion and beyond day 28 in one responding patient [103]. Notably, levels of IL-15 in peripheral blood prior to NK cell infusion were almost twofold higher in patients who showed a clinical response (Figure 1). Thus, in order to improve expansion and efficacy of NK cell therapy, recombinant (r) human IL-15 was tested in association with lymphodepleting chemotherapy and haploidentical NK cell infusion in AML patients [102]. The trial reported a high rate of adverse events, such as cytokine release syndrome (CRS) and neurotoxicity, after subcutaneous injection of IL-15, while achieving a $40 \%$ ORR. These results suggest that future studies should be undertaken to clarify the best way to use these agents.

Another approach to improve expansion, functionality and "memory" of NK cells is to use cytokine-induced memory-like (CIML) NK cells. These cells are obtained after IL-2, IL-15 and IL-18 cytokine preactivation, and low-dose IL-2 administration. They exhibit 
longer persistence and higher effector functions than control NK cells [104]. Currently, CIML NK cell therapy has only been tested in AML patients, and induced a clinical response in $50 \%$ of patients with poor prognosis, however no clinical trials have been performed for lymphoma patients [105]. Finally, exciting results have been reported more recently at an American Society of Hematology meeting, for a treatment called GCA-201 combining nicotinamide (NAM) and IL-15, which expanded allogeneic NK cells from healthy donors [106]. NAM plays a key role in metabolic reprogramming of cells and preserves cellular functionality and phenotype during ex vivo expansion. Nineteen R/R NHL patients were treated with GDA-201 and rituximab after lymphodepleting chemotherapy and achieved an ORR of $74 \%$ and a complete response (CR) rate of $67 \%$, without any remarkable toxicities. Median duration of response was 8.7 months, eight patients remained in $\mathrm{CR}$ without other treatment, and one of them maintained the response for 24 months. Flow cytometry confirmed the persistence of GDA-201 in peripheral blood for 7-10 days, as well as enhanced in vivo proliferation and trafficking to the bone marrow and lymph nodes.

\subsection{Chimeric Antigen-Receptor NK Cells (CAR-NK)}

Finally, interest is growing surrounding CAR-NK cells, which could overcome the limits of other adoptive therapies. CAR-NK cells have the potential to be rapid, offthe-shelf and cheaper products, without the need for HLA-matching and without major adverse effects (permitting repeated doses) (Figure 1). Anti-CD19 CAR-NK cells were constructed from umbilical cord blood using a retroviral vector that expresses genes that encode anti-CD19 CAR, IL-15 and inducible caspase 9 to trigger apoptosis in the case of unacceptable toxicity. This product was tested in phase 1 and 2 trials for the treatment of heavily pre-treated R/R CLL and NHL, and persisted for at least 12 months in the peripheral blood. It was associated with a $73 \%$ ORR and a $64 \%$ CR rate (7 of 11 patients), without any major toxicity [107]. All of the responses occurred during the first month after infusion and one patient maintained the CR for 13 months without further treatment. Nevertheless, the majority of responding patients were given other treatment after the CAR-NK cell infusion, which makes it difficult to draw conclusions about the durability of the response. These results are very encouraging and further studies are needed to address the issue of response duration. Several clinical trials of CAR-NK cells targeting CD19 or CD22 are ongoing for lymphoma patients (NCT04639739, NCT03056339, NCT04245722). Notably, CIML-CAR-NK cells are also in development for use in NK-resistant lymphoma patients [108].

\section{Conclusions}

Throughout this review, we have highlighted the many different roles that NK cells perform in the context of PTLDs. NK cells as innate cytotoxic sentinels against tumors and viral infections are the first line of protection that limits cellular transformation at the early stages. Although rare, NK cells can also be the origin of PTLD and develop as NK cell lymphomas. Yet, the primary role of NK cells is their participation in PTLD immunopathology through the acquired alterations that limit their capacity to control tumor growth, as well as their complementary role with other cellular components of the immune system. Finally, the most recently discovered role of NK cells in PTLDs is their use in PTLD therapy, both as ADCC effectors and as a therapeutic product by themselves through the different applications of NK cell infusions in current development.

Funding: This review was supported by the Institut National de la Recherche Médicale (Inserm). C. N-C. was supported by a PhD grant (C.N.-C; TAQK18773) from La Ligue contre le cancer, and M.B. by a "poste d'accueil" Inserm.

Conflicts of Interest: All authors declare no conflict of interest. The funders had no role in the content of the review or the writing of the manuscript. 


\begin{abstract}
Abbreviations
Acute myeloid leukemia (AML); ADAM Metallopeptidase Domain 17 (ADAM17); antibody dependent cellular cytotoxicity (ADCC); BamHI-A rightward transcript-2 (BART2); bispecific killer engagers (BiKE); chimeric antigen-receptor NK cells (CAR-NK); chronic lymphoid leukemias (CLL); cytokine-induced memory-like (CIML); cytokine release syndrome (CRS); Epstein-Barr virus (EBV); hematopoietic stem cell transplantation (HSCT); human herpesvirus-8 (HHV-8); human leukocyte antigens (HLA); Ig-like transcript-2 (ILT-2); interferon gamma (IFN- $\gamma$ ); immunoglobulin (Ig); interleukin (IL); infectious mononucleosis (IM); killer cell immunoglobulin-like receptor (KIR); lymphocyte-activation gene 3 (Lag-3); low affinity immunoglobulin gamma Fc region receptor III-A (FcgRIII); microARN (miRNA); major histocompatibility complex class I (MHC-I); MHC class I polypeptide-related sequence B (MIC-B); natural cytotoxicity receptor (NCR); natural killer (NK); NK group 2 member A(NKG2A); NK group 2 member D (NKG2D); overall response rate (ORR); post-transplant lymphoproliferative disorders (PTLDs); programmed cell death protein 1 (PD1); programmed death-ligand 1 (PD-L1); progression-free survival (PFS); regulatory T cells (Tregs); single-chain variable fragments (scFvs); solid organ transplantation (SOT); T-cell receptor (TCR); T cell immunoglobulin and mucin domain-containing-3 (Tim-3); tri-specific killer engager (TriKE); tumor microenvironment (TME); tumor necrosis factor alpha (TNF- $\alpha$ ); World Health Organization (WHO).
\end{abstract}

\title{
References
}

1. Lanier, L.L.; Le, A.M.; Phillips, J.H.; Warner, N.L.; Babcock, G.F. Subpopulations of Human Natural Killer Cells Defined by Expression of the Leu-7 (HNK-1) and Leu-11 (NK-15) Antigens. J. Immunol. 1983, 131, 1789-1796.

2. Trinchieri, G. Biology of Natural Killer Cells. In Advances in Immunology; Elsevier: Amsterdam, The Netherlands, 1989; Volume 47, pp. 187-376. ISBN 978-0-12-022447-0.

3. Sivori, S.; Vacca, P.; Del Zotto, G.; Munari, E.; Mingari, M.C.; Moretta, L. Human NK Cells: Surface Receptors, Inhibitory Checkpoints, and Translational Applications. Cell Mol. Immunol. 2019, 16, 430-441. [CrossRef]

4. Crome, S.Q.; Lang, P.A.; Lang, K.S.; Ohashi, P.S. Natural Killer Cells Regulate Diverse T Cell Responses. Trends Immunol. 2013, 34, 342-349. [CrossRef]

5. Meza Guzman, L.G.; Keating, N.; Nicholson, S.E. Natural Killer Cells: Tumor Surveillance and Signaling. Cancers 2020, $12,952$. [CrossRef] [PubMed]

6. Hammer, Q.; Rückert, T.; Romagnani, C. Natural Killer Cell Specificity for Viral Infections. Nat. Immunol. 2018, 19, 800-808. [CrossRef]

7. Pappworth, I.Y.; Wang, E.C.; Rowe, M. The Switch from Latent to Productive Infection in Epstein-Barr Virus-Infected B Cells Is Associated with Sensitization to NK Cell Killing. J. Virol. 2007, 81, 474-482. [CrossRef]

8. Azzi, T.; Lünemann, A.; Murer, A.; Ueda, S.; Béziat, V.; Malmberg, K.-J.; Staubli, G.; Gysin, C.; Berger, C.; Münz, C.; et al. Role for Early-Differentiated Natural Killer Cells in Infectious Mononucleosis. Blood 2014, 124, 2533-2543. [CrossRef]

9. Eidenschenk, C.; Dunne, J.; Jouanguy, E.; Fourlinnie, C.; Gineau, L.; Bacq, D.; McMahon, C.; Smith, O.; Casanova, J.-L.; Abel, L.; et al. A Novel Primary Immunodeficiency with Specific Natural-Killer Cell Deficiency Maps to the Centromeric Region of Chromosome 8. Am. J. Hum. Genet. 2006, 78, 721-727. [CrossRef]

10. Gineau, L.; Cognet, C.; Kara, N.; Lach, F.P.; Dunne, J.; Veturi, U.; Picard, C.; Trouillet, C.; Eidenschenk, C.; Aoufouchi, S.; et al. Partial MCM4 Deficiency in Patients with Growth Retardation, Adrenal Insufficiency, and Natural Killer Cell Deficiency. J. Clin. Investig. 2012, 122, 821-832. [CrossRef] [PubMed]

11. Mace, E.M.; Orange, J.S. Emerging Insights into Human Health and NK Cell Biology from the Study of NK Cell Deficiencies. Immunol. Rev. 2019, 287, 202-225. [CrossRef]

12. Baiocchi, R.A.; Ward, J.S.; Carrodeguas, L.; Eisenbeis, C.F.; Peng, R.; Roychowdhury, S.; Vourganti, S.; Sekula, T.; O’Brien, M.; Moeschberger, M.; et al. GM-CSF and IL-2 Induce Specific Cellular Immunity and Provide Protection against Epstein-Barr Virus Lymphoproliferative Disorder. J. Clin. Investig. 2001, 108, 887-894. [CrossRef]

13. Chijioke, O.; Müller, A.; Feederle, R.; Barros, M.H.M.; Krieg, C.; Emmel, V.; Marcenaro, E.; Leung, C.S.; Antsiferova, O.; Landtwing, V.; et al. Human Natural Killer Cells Prevent Infectious Mononucleosis Features by Targeting Lytic Epstein-Barr Virus Infection. Cell Rep. 2013, 5, 1489-1498. [CrossRef]

14. Hatton, O.; Strauss-Albee, D.M.; Zhao, N.Q.; Haggadone, M.D.; Pelpola, J.S.; Krams, S.M.; Martinez, O.M.; Blish, C.A. NKG2AExpressing Natural Killer Cells Dominate the Response to Autologous Lymphoblastoid Cells Infected with Epstein-Barr Virus. Front. Immunol. 2016, 7, 607. [CrossRef]

15. Djaoud, Z.; Guethlein, L.A.; Horowitz, A.; Azzi, T.; Nemat-Gorgani, N.; Olive, D.; Nadal, D.; Norman, P.J.; Münz, C.; Parham, P. Two Alternate Strategies for Innate Immunity to Epstein-Barr Virus: One Using NK Cells and the Other NK Cells and $\Gamma \delta$ T Cells. J. Exp. Med. 2017, 214, 1827-1841. [CrossRef] 
16. Mbiribindi, B.; Pena, J.K.; Arvedson, M.P.; Moreno Romero, C.; McCarthy, S.R.; Hatton, O.L.; Esquivel, C.O.; Martinez, O.M.; Krams, S.M. Epstein-Barr Virus Peptides Derived from Latent Cycle Proteins Alter NKG2A + NK Cell Effector Function. Sci. Rep. 2020, 10, 19973. [CrossRef]

17. Münz, C. Tumor Microenvironment Conditioning by Abortive Lytic Replication of Oncogenic $\gamma$-Herpesviruses. Adv. Exp. Med. Biol. 2020, 1225, 127-135. [CrossRef]

18. Dierickx, D.; Habermann, T.M. Post-Transplantation Lymphoproliferative Disorders in Adults. N. Engl. J. Med. 2018, 378, 549-562. [CrossRef]

19. Dharnidharka, V.R.; Webster, A.C.; Martinez, O.M.; Preiksaitis, J.K.; Leblond, V.; Choquet, S. Post-Transplant Lymphoproliferative Disorders. Nat. Rev. Dis. Primers 2016, 2, 15088. [CrossRef] [PubMed]

20. Leblond, V.; Davi, F.; Charlotte, F.; Dorent, R.; Bitker, M.O.; Sutton, L.; Gandjbakhch, I.; Binet, J.L.; Raphael, M. Posttransplant Lymphoproliferative Disorders Not Associated with Epstein-Barr Virus: A Distinct Entity? J. Clin. Oncol. 1998, 16, 2052-2059. [CrossRef] [PubMed]

21. Luskin, M.R.; Heil, D.S.; Tan, K.S.; Choi, S.; Stadtmauer, E.A.; Schuster, S.J.; Porter, D.L.; Vonderheide, R.H.; Bagg, A.; Heitjan, D.F.; et al. The Impact of EBV Status on Characteristics and Outcomes of Posttransplantation Lymphoproliferative Disorder. Am. J. Transplant. 2015, 15, 2665-2673. [CrossRef] [PubMed]

22. Martinez, O.M.; Krams, S.M. The Immune Response to Epstein Barr Virus and Implications for Posttransplant Lymphoproliferative Disorder. Transplantation 2017, 101, 2009-2016. [CrossRef]

23. Swerdlow, S.H.; Campo, E.; Pileri, S.A.; Harris, N.L.; Stein, H.; Siebert, R.; Advani, R.; Ghielmini, M.; Salles, G.A.; Zelenetz, A.D.; et al. The 2016 Revision of the World Health Organization Classification of Lymphoid Neoplasms. Blood 2016, 127, 2375-2390. [CrossRef]

24. Swerdlow, S.H. T-Cell and NK-Cell Posttransplantation Lymphoproliferative Disorders. Am. J. Clin. Pathol. 2007, 127, 887-895. [CrossRef]

25. Mohapatra, A.; Viswabandya, A.; Samuel, R.; Deepti, A.N.; Madhivanan, S.; John, G.T. NK/T-Cell Lymphoma in a Renal Transplant Recipient and Review of Literature. Indian J. Nephrol. 2011, 21, 44-47. [CrossRef]

26. Matsumura, M.; Mizuno, Y.; Okamoto, M.; Sawa, N.; Katayama, Y.; Shimoyama, N.; Kawagishi, N.; Miura, K. Long-Term Complete Remission of Multiple Extranodal Natural Killer/T-Cell-Type Posttransplant Lymphoproliferative Disorder after Surgical Resection: A Case Report. Transpl. Proc. 2014, 46, 2373-2376. [CrossRef] [PubMed]

27. Gooptu, M.; Kim, H.T.; Chen, Y.-B.; Rybka, W.; Artz, A.; Boyer, M.; Johnston, L.; McGuirk, J.; Shea, T.C.; Jagasia, M.; et al. Effect of Antihuman T Lymphocyte Globulin on Immune Recovery after Myeloablative Allogeneic Stem Cell Transplantation with Matched Unrelated Donors: Analysis of Immune Reconstitution in a Double-Blind Randomized Controlled Trial. Biol. Blood Marrow Transpl. 2018, 24, 2216-2223. [CrossRef]

28. Hadaya, K.; Avila, Y.; Valloton, L.; de Rham, C.; Bandelier, C.; Ferrari-Lacraz, S.; Pascual, M.; Pantaleo, G.; Martin, P.Y.; Buhler, L.; et al. Natural Killer Cell Receptor-Repertoire and Functions after Induction Therapy by Polyclonal Rabbit Anti-Thymocyte Globulin in Unsensitized Kidney Transplant Recipients. Clin. Immunol. 2010, 137, 250-260. [CrossRef] [PubMed]

29. Kho, M.M.L.; Bouvy, A.P.; Cadogan, M.; Kraaijeveld, R.; Baan, C.C.; Weimar, W. The Effect of Low and Ultra-Low Dosages Thymoglobulin on Peripheral T, B and NK Cells in Kidney Transplant Recipients. Transpl. Immunol. 2012, 26, 186-190. [CrossRef]

30. Müller, T.F.; Grebe, S.O.; Neumann, M.C.; Heymanns, J.; Radsak, K.; Sprenger, H.; Lange, H. Persistent Long-Term Changes in Lymphocyte Subsets Induced by Polyclonal Antibodies. Transplantation 1997, 64, 1432-1437. [CrossRef]

31. Savani, B.N.; Mielke, S.; Adams, S.; Uribe, M.; Rezvani, K.; Yong, A.S.M.; Zeilah, J.; Kurlander, R.; Srinivasan, R.; Childs, R.; et al. Rapid Natural Killer Cell Recovery Determines Outcome after T-Cell-Depleted HLA-Identical Stem Cell Transplantation in Patients with Myeloid Leukemias but Not with Acute Lymphoblastic Leukemia. Leukemia 2007, 21, 2145-2152. [CrossRef]

32. Nakid-Cordero, C.; Choquet, S.; Gauthier, N.; Balegroune, N.; Tarantino, N.; Morel, V.; Arzouk, N.; Burrel, S.; Rousseau, G.; Charlotte, F.; et al. Distinct Immunopathological Mechanisms of EBV-positive and EBV-negative Posttransplant Lymphoproliferative Disorders. Am. J. Transplant. 2021, ajt.16547. [CrossRef]

33. Baychelier, F.; Achour, A.; Nguyen, S.; Raphael, M.; Toubert, A.; Besson, C.; Arnoux, A.; Roos-Weil, D.; Marty, M.; Chapelier, A.; et al. Natural Killer Cell Deficiency in Patients with Non-Hodgkin Lymphoma after Lung Transplantation. J. Heart Lung Transpl. 2015, 34, 604-612. [CrossRef]

34. Wiesmayr, S.; Webber, S.A.; Macedo, C.; Popescu, I.; Smith, L.; Luce, J.; Metes, D. Decreased NKp46 and NKG2D and Elevated PD-1 Are Associated with Altered NK-Cell Function in Pediatric Transplant Patients with PTLD. Eur. J. Immunol. 2012, 42, 541-550. [CrossRef] [PubMed]

35. Bergerson, R.J.; Williams, R.; Wang, H.; Shanley, R.; Colbenson, G.; Kerber, A.; Cooley, S.; Curtsinger, J.; Felices, M.; Miller, J.S.; et al. Fewer Circulating Natural Killer Cells 28 Days After Double Cord Blood Transplantation Predicts Inferior Survival and IL-15 Response. Blood Adv. 2016, 1, 208-218. [CrossRef] [PubMed]

36. Neudoerfl, C.; Mueller, B.J.; Blume, C.; Daemen, K.; Stevanovic-Meyer, M.; Keil, J.; Lehner, F.; Haller, H.; Falk, C.S. The Peripheral NK Cell Repertoire after Kidney Transplantation Is Modulated by Different Immunosuppressive Drugs. Front. Immunol. 2013, 4, 1-14. [CrossRef] [PubMed]

37. Peraldi, M.N.; Berrou, J.; Venot, M.; Chardiny, V.; Durrbach, A.; Vieillard, V.; Debré, P.; Charron, D.; Suberbielle, C.; Chevret, S.; et al. Natural Killer Lymphocytes Are Dysfunctional in Kidney Transplant Recipients on Diagnosis of Cancer. Transplantation 2015, 99, 2422-2430. [CrossRef] [PubMed] 
38. Wang, H.; Grzywacz, B.; Sukovich, D.; McCullar, V.; Cao, Q.; Lee, A.B.; Blazar, B.R.; Cornfield, D.N.; Miller, J.S.; Verneris, M.R. The Unexpected Effect of Cyclosporin A on CD56+CD16- and CD56+CD16+ Natural Killer Cell Subpopulations. Blood 2007, 110, 1530-1539. [CrossRef]

39. González, J.P.; Zabaleta, A.; Sangro, P.; Basualdo, J.E.; Burgos, L.; Paiva, B.; Herrero, J.I. Immunophenotypic Pattern of De Novo Malignancy After Liver Transplantation. Transpl. Proc. 2019, 51, 77-79. [CrossRef]

40. Sundström, Y.; Nilsson, C.; Lilja, G.; Kärre, K.; Troye-Blomberg, M.; Berg, L. The Expression of Human Natural Killer Cell Receptors in Early Life. Scand. J. Immunol. 2007, 66, 335-344. [CrossRef]

41. Zhang, B.; Kracker, S.; Yasuda, T.; Casola, S.; Vanneman, M.; Hömig-Hölzel, C.; Wang, Z.; Derudder, E.; Li, S.; Chakraborty, T.; et al. Immune Surveillance and Therapy of Lymphomas Driven by Epstein-Barr Virus Protein LMP1 in a Mouse Model. Cell 2012, 148, 739-751. [CrossRef]

42. Nachmani, D.; Stern-Ginossar, N.; Sarid, R.; Mandelboim, O. Diverse Herpesvirus MicroRNAs Target the Stress-Induced Immune Ligand MICB to Escape Recognition by Natural Killer Cells. Cell Host Microbe 2009, 5, 376-385. [CrossRef] [PubMed]

43. Forconi, C.S.; Cosgrove, C.P.; Saikumar-Lakshmi, P.; Nixon, C.E.; Foley, J.; Ong'echa, J.M.; Otieno, J.A.; Alter, G.; Münz, C.; Moormann, A.M. Poorly Cytotoxic Terminally Differentiated CD56negCD16pos NK Cells Accumulate in Kenyan Children with Burkitt Lymphomas. Blood Adv. 2018, 2, 1101-1114. [CrossRef]

44. Beldi-Ferchiou, A.; Lambert, M.; Dogniaux, S.; Vély, F.; Vivier, E.; Olive, D.; Dupuy, S.; Levasseur, F.; Zucman, D.; Lebbé, C.; et al. PD-1 Mediates Functional Exhaustion of Activated NK Cells in Patients with Kaposi Sarcoma. Oncotarget 2016, 7. [CrossRef] [PubMed]

45. Bi, J.; Tian, Z. NK Cell Exhaustion. Front. Immunol. 2017, 8, 760. [CrossRef] [PubMed]

46. Pesce, S.; Greppi, M.; Tabellini, G.; Rampinelli, F.; Parolini, S.; Olive, D.; Moretta, L.; Moretta, A.; Marcenaro, E. Identification of a Subset of Human Natural Killer Cells Expressing High Levels of Programmed Death 1: A Phenotypic and Functional Characterization. J. Allergy Clin. Immunol. 2017, 139, 335-346. [CrossRef] [PubMed]

47. Nakid-Cordero, C.; Arzouk, N.; Gauthier, N.; Tarantino, N.; Larsen, M.; Choquet, S.; Burrel, S.; Autran, B.; Vieillard, V.; Guihot, A. Skewed T Cell Responses to Epstein-Barr Virus in Long-Term Asymptomatic Kidney Transplant Recipients. PLoS ONE 2019, 14, e0224211. [CrossRef]

48. Liu, Y.; Cheng, Y.; Xu, Y.; Wang, Z.; Du, X.; Li, C.; Peng, J.; Gao, L.; Liang, X.; Ma, C. Increased Expression of Programmed Cell Death Protein 1 on NK Cells Inhibits NK-Cell-Mediated Anti-Tumor Function and Indicates Poor Prognosis in Digestive Cancers. Oncogene 2017, 36, 6143-6153. [CrossRef]

49. Pittari, G.; Vago, L.; Festuccia, M.; Bonini, C.; Mudawi, D.; Giaccone, L.; Bruno, B. Restoring Natural Killer Cell Immunity against Multiple Myeloma in the Era of New Drugs. Front. Immunol. 2017, 8, 1444. [CrossRef]

50. Green, M.R.; Rodig, S.; Juszczynski, P.; Ouyang, J.; Sinha, P.; O’Donnell, E.; Neuberg, D.; Shipp, M.A. Constitutive AP-1 Activity and EBV Infection Induce PD-L1 in Hodgkin Lymphomas and Posttransplant Lymphoproliferative Disorders: Implications for Targeted Therapy. Clin. Cancer Res. 2012, 18, 1611-1618. [CrossRef]

51. Kinch, A.; Sundström, C.; Baecklund, E.; Backlin, C.; Molin, D.; Enblad, G. Expression of PD-1, PD-L1, and PD-L2 in Posttransplant Lymphoproliferative Disorder after Solid Organ Transplantation. Leuk. Lymphoma 2018, 60, 376-384. [CrossRef]

52. Benson, D.M.; Bakan, C.E.; Mishra, A.; Hofmeister, C.C.; Efebera, Y.; Becknell, B.; Baiocchi, R.A.; Zhang, J.; Yu, J.; Smith, M.K.; et al. The PD-1/PD-L1 Axis Modulates the Natural Killer Cell versus Multiple Myeloma Effect: A Therapeutic Target for CT-011, a Novel Monoclonal Anti-PD-1 Antibody. Blood 2010, 116, 2286-2294. [CrossRef] [PubMed]

53. Chae, Y.K.; Galvez, C.; Anker, J.F.; Iams, W.T.; Bhave, M. Cancer Immunotherapy in a Neglected Population: The Current Use and Future of T-Cell-Mediated Checkpoint Inhibitors in Organ Transplant Patients. Cancer Treat. Rev. 2018, 63, 116-121. [CrossRef] [PubMed]

54. Fisher, J.; Zeitouni, N.; Fan, W.; Samie, F.H. Immune Checkpoint Inhibitor Therapy in Solid Organ Transplant Recipients: A Patient-Centered Systematic Review. J. Am. Acad. Dermatol. 2020, 82, 1490-1500. [CrossRef] [PubMed]

55. Jones, K.; Nourse, J.P.; Morrison, L.; Nguyen-Van, D.; Moss, D.J.; Burrows, S.R.; Gandhi, M.K. Expansion of EBNA1-Specific Effector T Cells in Posttransplantation Lymphoproliferative Disorders. Blood 2010, 116, 2245-2252. [CrossRef] [PubMed]

56. Calarota, S.A.; Chiesa, A.; Zelini, P.; Comolli, G.; Minoli, L.; Baldanti, F. Detection of Epstein-Barr Virus-Specific Memory CD4+ T Cells Using a Peptide-Based Cultured Enzyme-Linked Immunospot Assay. Immunology 2013, 139, 533-544. [CrossRef]

57. Morscio, J.; Dierickx, D.; Ferreiro, J.F.; Herreman, A.; Van Loo, P.; Bittoun, E.; Verhoef, G.; Matthys, P.; Cools, J.; Wlodarska, I.; et al. Gene Expression Profiling Reveals Clear Differences Between EBV-Positive and EBV-Negative Posttransplant Lymphoproliferative Disorders. Am. J. Transpl. 2013, 13, 1305-1316. [CrossRef]

58. Jog, N.R.; Chakravarty, E.F.; Guthridge, J.M.; James, J.A. Epstein Barr Virus Interleukin 10 Suppresses Anti-Inflammatory Phenotype in Human Monocytes. Front. Immunol. 2018, 9, 1-11. [CrossRef]

59. Muti, G.; Klersy, C.; Baldanti, F.; Granata, S.; Oreste, P.; Pezzetti, L.; Gatti, M.; Gargantini, L.; Caramella, M.; Mancini, V. Epstein-Barr Virus (EBV) Load and Interleukin-10 in Lymphoproliferative Disorders. Br. J. Haematol. 2003, 122, 927-933. [CrossRef]

60. Marcelis, L.; Tousseyn, T. The Tumor Microenvironment in Post-Transplant Lymphoproliferative Disorders. Cancer Microenviron. 2019. [CrossRef]

61. Quinlan, S.C.; Pfeiffer, R.M.; Morton, L.M.; Engels, E.A. Risk Factors for Early-Onset and Late-Onset Post-Transplant Lymphoproliferative Disorder in Kidney Recipients in the United States. Am. J. Hematol. 2011, 86, 206-209. [CrossRef] 
62. Naik, S.; Riches, M.; Hari, P.; Kim, S.; Chen, M.; Bachier, C.; Shaughnessy, P.; Hill, J.; Ljungman, P.; Battiwalla, M.; et al. Survival Outcomes of Allogeneic Hematopoietic Cell Transplants with EBV-positive or EBV-negative Post-transplant Lymphoproliferative Disorder, A CIBMTR Study. Transpl. Infect. Dis. 2019, 21, e13145. [CrossRef] [PubMed]

63. Dierickx, D.; Tousseyn, T.; Sagaert, X.; Fieuws, S.; Wlodarska, I.; Morscio, J.; Brepoels, L.; Kuypers, D.; Vanhaecke, J.; Nevens, F.; et al. Single-Center Analysis of Biopsy-Confirmed Posttransplant Lymphoproliferative Disorder: Incidence, Clinicopathological Characteristics and Prognostic Factors. Leuk. Lymphoma 2013, 54, 2433-2440. [CrossRef]

64. Bishnoi, R.; Minish, J.; Franke, A.J.; Skelton, W.P.; Shah, C.P.; Wang, Y.; Dang, N.H. Single-Institution Retrospective Analysis of Prognostic Factors Influencing Very Late-Onset Post-Transplant Lymphoproliferative Disorder. Cureus 2020, 12. [CrossRef]

65. Ndhlovu, L.C.; Lopez-Verge, S.; Barbour, J.D.; Jones, R.B.; Jha, A.R.; Long, B.R.; Schoeffler, E.C.; Fujita, T.; Nixon, D.F.; Lanier, L.L. Tim-3 Marks Human Natural Killer Cell Maturation and Suppresses Cell-Mediated Cytotoxicity. Blood 2012, 119, 3734-3743. [CrossRef]

66. Gonçalves Silva, I.; Yasinska, I.M.; Sakhnevych, S.S.; Fiedler, W.; Wellbrock, J.; Bardelli, M.; Varani, L.; Hussain, R.; Siligardi, G.; Ceccone, G.; et al. The Tim-3-Galectin-9 Secretory Pathway Is Involved in the Immune Escape of Human Acute Myeloid Leukemia Cells. EBioMedicine 2017, 22, 44-57. [CrossRef]

67. Tallerico, R.; Cristiani, C.M.; Staaf, E.; Garofalo, C.; Sottile, R.; Capone, M.; Pico de Coaña, Y.; Madonna, G.; Palella, E.; Wolodarski, M.; et al. IL-15, TIM-3 and NK Cells Subsets Predict Responsiveness to Anti-CTLA-4 Treatment in Melanoma Patients. OncoImmunology 2017, 6, e1261242. [CrossRef] [PubMed]

68. Hadadi, L.; Hafezi, M.; Amirzargar, A.A.; Sharifian, R.A.; Abediankenari, S.; Asgarian-Omran, H. Dysregulated Expression of Tim-3 and NKp30 Receptors on NK Cells of Patients with Chronic Lymphocytic Leukemia. Oncol. Res. Treat. 2019, 42, 197-203. [CrossRef] [PubMed]

69. So, E.C.; Khaladj-Ghom, A.; Ji, Y.; Amin, J.; Song, Y.; Burch, E.; Zhou, H.; Sun, H.; Chen, S.; Bentzen, S.; et al. NK Cell Expression of Tim-3: First Impressions Matter. Immunobiology 2019, 224, 362-370. [CrossRef] [PubMed]

70. Xu, L.; Huang, Y.; Tan, L.; Yu, W.; Chen, D.; Lu, C.; He, J.; Wu, G.; Liu, X.; Zhang, Y. Increased Tim-3 Expression in Peripheral NK Cells Predicts a Poorer Prognosis and Tim-3 Blockade Improves NK Cell-Mediated Cytotoxicity in Human Lung Adenocarcinoma. Int. Immunopharmacol. 2015, 29, 635-641. [CrossRef]

71. Weng, W.-K.; Levy, R. Two Immunoglobulin G Fragment C Receptor Polymorphisms Independently Predict Response to Rituximab in Patients with Follicular Lymphoma. J. Clin. Oncol. 2003, 21, 3940-3947. [CrossRef]

72. Cartron, G.; Dacheux, L.; Salles, G.; Solal-Celigny, P.; Bardos, P.; Colombat, P.; Watier, H. Therapeutic Activity of Humanized Anti-CD20 Monoclonal Antibody and Polymorphism in IgG Fc Receptor FcgammaRIIIa Gene. Blood 2002, 99, 754-758. [CrossRef]

73. Weng, W.-K.; Negrin, R.S.; Lavori, P.; Horning, S.J. Immunoglobulin G Fc Receptor FcgammaRIIIa 158 V/F Polymorphism Correlates with Rituximab-Induced Neutropenia after Autologous Transplantation in Patients with Non-Hodgkin's Lymphoma. J. Clin. Oncol. 2010, 28, 279-284. [CrossRef] [PubMed]

74. Shields, R.L.; Namenuk, A.K.; Hong, K.; Meng, Y.G.; Rae, J.; Briggs, J.; Xie, D.; Lai, J.; Stadlen, A.; Li, B.; et al. High Resolution Mapping of the Binding Site on Human IgG1 for Fc Gamma RI, Fc Gamma RII, Fc Gamma RIII, and FcRn and Design of IgG1 Variants with Improved Binding to the Fc Gamma R. J. Biol. Chem. 2001, 276, 6591-6604. [CrossRef] [PubMed]

75. Weng, W.-K.; Czerwinski, D.; Timmerman, J.; Hsu, F.J.; Levy, R. Clinical Outcome of Lymphoma Patients after Idiotype Vaccination Is Correlated with Humoral Immune Response and Immunoglobulin G Fc Receptor Genotype. J. Clin. Oncol. 2004, 22, 4717-4724. [CrossRef]

76. Weng, W.-K.; Weng, W.-K.; Levy, R. Immunoglobulin G Fc Receptor Polymorphisms Do Not Correlate with Response to Chemotherapy or Clinical Course in Patients with Follicular Lymphoma. Leuk. Lymphoma 2009, 50, 1494-1500. [CrossRef] [PubMed]

77. Awasthi, A.; Ayello, J.; Van de Ven, C.; Elmacken, M.; Sabulski, A.; Barth, M.J.; Czuczman, M.S.; Islam, H.; Klein, C.; Cairo, M.S. Obinutuzumab (GA101) Compared to Rituximab Significantly Enhances Cell Death and Antibody-Dependent Cytotoxicity and Improves Overall Survival against CD20(+) Rituximab-Sensitive/-Resistant Burkitt Lymphoma (BL) and Precursor B-Acute Lymphoblastic Leukaemia (Pre-B-ALL): Potential Targeted Therapy in Patients with Poor Risk CD20(+) BL and Pre-B-ALL. Br. J. Haematol. 2015, 171, 763-775. [CrossRef]

78. Schmohl, J.U.; Gleason, M.K.; Dougherty, P.R.; Miller, J.S.; Vallera, D.A. Heterodimeric Bispecific Single Chain Variable Fragments $(\mathrm{ScFv})$ Killer Engagers (BiKEs) Enhance NK-Cell Activity Against CD133+ Colorectal Cancer Cells. Target. Oncol. 2016, 11, 353-361. [CrossRef]

79. Wiernik, A.; Foley, B.; Zhang, B.; Verneris, M.R.; Warlick, E.; Gleason, M.K.; Ross, J.A.; Luo, X.; Weisdorf, D.J.; Walcheck, B.; et al. Targeting Natural Killer Cells to Acute Myeloid Leukemia in Vitro with a CD16 x 33 Bispecific Killer Cell Engager and ADAM17 Inhibition. Clin. Cancer Res. 2013, 19, 3844-3855. [CrossRef]

80. Gleason, M.K.; Ross, J.A.; Warlick, E.D.; Lund, T.C.; Verneris, M.R.; Wiernik, A.; Spellman, S.; Haagenson, M.D.; Lenvik, A.J.; Litzow, M.R.; et al. CD16xCD33 Bispecific Killer Cell Engager (BiKE) Activates NK Cells against Primary MDS and MDSC CD33+ Targets. Blood 2014, 123, 3016-3026. [CrossRef]

81. Vallera, D.A.; Zhang, B.; Gleason, M.K.; Oh, S.; Weiner, L.M.; Kaufman, D.S.; McCullar, V.; Miller, J.S.; Verneris, M.R. Heterodimeric Bispecific Single-Chain Variable-Fragment Antibodies against EpCAM and CD16 Induce Effective Antibody-Dependent Cellular Cytotoxicity against Human Carcinoma Cells. Cancer Biother. Radiopharm. 2013, 28, 274-282. [CrossRef] 
82. Kuwahara, A.; Nagai, K.; Nakanishi, T.; Kumagai, I.; Asano, R. Functional Domain Order of an Anti-EGFR $\times$ Anti-CD16 Bispecific Diabody Involving NK Cell Activation. Int. J. Mol. Sci. 2020, 21, 8914. [CrossRef]

83. Thakur, A.; Huang, M.; Lum, L.G. Bispecific Antibody Based Therapeutics: Strengths and Challenges. Blood Rev. 2018, 32, 339-347. [CrossRef]

84. Schmohl, J.U.; Felices, M.; Taras, E.; Miller, J.S.; Vallera, D.A. Enhanced ADCC and NK Cell Activation of an Anticarcinoma Bispecific Antibody by Genetic Insertion of a Modified IL-15 Cross-Linker. Mol. Ther. 2016, 24, 1312-1322. [CrossRef]

85. Schmohl, J.U.; Felices, M.; Todhunter, D.; Taras, E.; Miller, J.S.; Vallera, D.A. Tetraspecific ScFv Construct Provides NK Cell Mediated ADCC and Self-Sustaining Stimuli via Insertion of IL-15 as a Cross-Linker. Oncotarget 2016, 7, 73830-73844. [CrossRef]

86. Cheng, Y.; Zheng, X.; Wang, X.; Chen, Y.; Wei, H.; Sun, R.; Tian, Z.; Sun, H. Trispecific Killer Engager 161519 Enhances Natural Killer Cell Function and Provides Anti-Tumor Activity against CD19-Positive Cancers. Cancer Biol. Med. 2020, 17, 1026-1038. [CrossRef] [PubMed]

87. Rothe, A.; Sasse, S.; Topp, M.S.; Eichenauer, D.A.; Hummel, H.; Reiners, K.S.; Dietlein, M.; Kuhnert, G.; Kessler, J.; Buerkle, C.; et al. A Phase 1 Study of the Bispecific Anti-CD30/CD16A Antibody Construct AFM13 in Patients with Relapsed or Refractory Hodgkin Lymphoma. Blood 2015, 125, 4024-4031. [CrossRef] [PubMed]

88. Bartlett, N.L.; Herrera, A.F.; Domingo-Domenech, E.; Mehta, A.; Forero-Torres, A.; Garcia-Sanz, R.; Armand, P.; Devata, S.; Izquierdo, A.R.; Lossos, I.S.; et al. A Phase 1b Study of AFM13 in Combination with Pembrolizumab in Patients with Relapsed or Refractory Hodgkin Lymphoma. Blood 2020, 136, 2401-2409. [CrossRef]

89. Felices, M.; Kodal, B.; Hinderlie, P.; Kaminski, M.F.; Cooley, S.; Weisdorf, D.J.; Vallera, D.A.; Miller, J.S.; Bachanova, V. Novel CD19-Targeted TriKE Restores NK Cell Function and Proliferative Capacity in CLL. Blood Adv. 2019, 3, 897-907. [CrossRef] [PubMed]

90. Gauthier, L.; Morel, A.; Anceriz, N.; Rossi, B.; Blanchard-Alvarez, A.; Grondin, G.; Trichard, S.; Cesari, C.; Sapet, M.; Bosco, F.; et al. Multifunctional Natural Killer Cell Engagers Targeting NKp46 Trigger Protective Tumor Immunity. Cell 2019, 177, 1701-1713. [CrossRef]

91. Burns, L.J.; Weisdorf, D.J.; DeFor, T.E.; Vesole, D.H.; Repka, T.L.; Blazar, B.R.; Burger, S.R.; Panoskaltsis-Mortari, A.; Keever-Taylor, C.A.; Zhang, M.-J.; et al. IL-2-Based Immunotherapy after Autologous Transplantation for Lymphoma and Breast Cancer Induces Immune Activation and Cytokine Release: A Phase I/II Trial. Bone Marrow Transpl. 2003, 32, 177-186. [CrossRef]

92. Smith, K.A. Interleukin-2: Inception, Impact, and Implications. Science 1988, 240, 1169-1176. [CrossRef] [PubMed]

93. Conlon, K.C.; Lugli, E.; Welles, H.C.; Rosenberg, S.A.; Fojo, A.T.; Morris, J.C.; Fleisher, T.A.; Dubois, S.P.; Perera, L.P.; Stewart, D.M.; et al. Redistribution, Hyperproliferation, Activation of Natural Killer Cells and CD8 T Cells, and Cytokine Production during First-in-Human Clinical Trial of Recombinant Human Interleukin-15 in Patients with Cancer. J. Clin. Oncol. 2015, 33, 74-82. [CrossRef]

94. Miller, J.S.; Morishima, C.; McNeel, D.G.; Patel, M.R.; Kohrt, H.E.K.; Thompson, J.A.; Sondel, P.M.; Wakelee, H.A.; Disis, M.L.; Kaiser, J.C.; et al. A First-in-Human Phase I Study of Subcutaneous Outpatient Recombinant Human IL15 (RhIL15) in Adults with Advanced Solid Tumors. Clin. Cancer Res. 2018, 24, 1525-1535. [CrossRef] [PubMed]

95. Romee, R.; Cooley, S.; Berrien-Elliott, M.M.; Westervelt, P.; Verneris, M.R.; Wagner, J.E.; Weisdorf, D.J.; Blazar, B.R.; Ustun, C.; DeFor, T.E.; et al. First-in-Human Phase 1 Clinical Study of the IL-15 Superagonist Complex ALT-803 to Treat Relapse after Transplantation. Blood 2018, 131, 2515-2527. [CrossRef] [PubMed]

96. Fehniger, T.A.; Hess, B.T.; Bachanova, V.; Becker-Hapak, M.; McClain, E.; Berrien-Elliott, M.; Wagner, J.; Bartlett, N.L.; Kahl, B.; Mehta-Shah, N.; et al. Abstract CT146: First-in-Human Phase I Combination of the IL-15 Receptor Super Agonist Complex ALT803 with a Therapeutic (Anti-CD20) Monoclonal Antibody (MAb) for Patients with Relapsed or Refractory Indolent Non-Hodgkin Lymphoma (INHL). Cancer Res. 2018, 78, CT146. [CrossRef]

97. Parkhurst, M.R.; Riley, J.P.; Dudley, M.E.; Rosenberg, S.A. Adoptive Transfer of Autologous Natural Killer Cells Leads to High Levels of Circulating Natural Killer Cells but Does Not Mediate Tumor Regression. Clin. Cancer Res. 2011, 17, 6287-6297. [CrossRef]

98. Rosenberg, S.A.; Lotze, M.T.; Muul, L.M.; Leitman, S.; Chang, A.E.; Ettinghausen, S.E.; Matory, Y.L.; Skibber, J.M.; Shiloni, E.; Vetto, J.T. Observations on the Systemic Administration of Autologous Lymphokine-Activated Killer Cells and Recombinant Interleukin-2 to Patients with Metastatic Cancer. N. Engl. J. Med. 1985, 313, 1485-1492. [CrossRef]

99. Rosenberg, S.A.; Restifo, N.P.; Yang, J.C.; Morgan, R.A.; Dudley, M.E. Adoptive Cell Transfer: A Clinical Path to Effective Cancer Immunotherapy. Nat. Rev. Cancer 2008, 8, 299-308. [CrossRef]

100. Bachanova, V.; Cooley, S.; Defor, T.E.; Verneris, M.R.; Zhang, B.; McKenna, D.H.; Curtsinger, J.; Panoskaltsis-Mortari, A.; Lewis, D.; Hippen, K.; et al. Clearance of Acute Myeloid Leukemia by Haploidentical Natural Killer Cells Is Improved Using IL-2 Diphtheria Toxin Fusion Protein. Blood 2014, 123, 3855-3863. [CrossRef]

101. Miller, J.S.; Soignier, Y.; Panoskaltsis-Mortari, A.; McNearney, S.A.; Yun, G.H.; Fautsch, S.K.; McKenna, D.; Le, C.; Defor, T.E.; Burns, L.J.; et al. Successful Adoptive Transfer and in Vivo Expansion of Human Haploidentical NK Cells in Patients with Cancer. Blood 2005, 105, 3051-3057. [CrossRef]

102. Cooley, S.; He, F.; Bachanova, V.; Vercellotti, G.M.; DeFor, T.E.; Curtsinger, J.M.; Robertson, P.; Grzywacz, B.; Conlon, K.C.; Waldmann, T.A.; et al. First-in-Human Trial of RhIL-15 and Haploidentical Natural Killer Cell Therapy for Advanced Acute Myeloid Leukemia. Blood Adv. 2019, 3, 1970-1980. [CrossRef] [PubMed] 
103. Bachanova, V.; Sarhan, D.; DeFor, T.E.; Cooley, S.; Panoskaltsis-Mortari, A.; Blazar, B.R.; Curtsinger, J.M.; Burns, L.; Weisdorf, D.J.; Miller, J.S. Haploidentical Natural Killer Cells Induce Remissions in Non-Hodgkin Lymphoma Patients with Low Levels of Immune-Suppressor Cells. Cancer Immunol. Immunother. 2018, 67, 483-494. [CrossRef] [PubMed]

104. Berrien-Elliott, M.M.; Wagner, J.A.; Fehniger, T.A. Human Cytokine-Induced Memory-Like Natural Killer Cells. J. Innate Immun. 2015, 7, 563-571. [CrossRef]

105. Romee, R.; Rosario, M.; Berrien-Elliott, M.M.; Wagner, J.A.; Jewell, B.A.; Schappe, T.; Leong, J.W.; Abdel-Latif, S.; Schneider, S.E.; Willey, S.; et al. Cytokine-Induced Memory-like Natural Killer Cells Exhibit Enhanced Responses against Myeloid Leukemia. Sci. Transl. Med. 2016, 8, 357ra123. [CrossRef]

106. Bachanova, V.; Maakaron, J.; McKenna, D.H.; Cao, Q.; DeFor, T.E.; He, F.; Janakiram, M.; Wangen, R.; Cayci, Z.; Grzywacz, B.; et al. Results of a Phase 1 Trial of Gda-201, Nicotinamide-Expanded Allogeneic Natural Killer (NK) Cells in Patients with Refractory Non-Hodgkin Lymphoma (NHL) and Multiple Myeloma. Blood 2020, 136, 6. [CrossRef]

107. Liu, E.; Marin, D.; Banerjee, P.; Macapinlac, H.A.; Thompson, P.; Basar, R.; Nassif Kerbauy, L.; Overman, B.; Thall, P.; Kaplan, M.; et al. Use of CAR-Transduced Natural Killer Cells in CD19-Positive Lymphoid Tumors. N. Engl. J. Med. 2020, 382, 545-553. [CrossRef] [PubMed]

108. Gang, M.; Marin, N.D.; Wong, P.; Neal, C.C.; Marsala, L.; Foster, M.; Schappe, T.; Meng, W.; Tran, J.; Schaettler, M.; et al. CARModified Memory-like NK Cells Exhibit Potent Responses to NK-Resistant Lymphomas. Blood 2020, 136, 2308-2318. [CrossRef] [PubMed] 